\title{
EPILITHIC COMMUNITY DEVELOPMENT ON ARTIFICIAL REEFS DEPLOYED ALONG A CROSS-SHELF ENVIRONMENTAL GRADIENT OFF PARANÁ STATE, SOUTHERN BRAZIL*
}

\author{
Frederico Brandini ${ }^{\text {*** }}$ and Ariel Scheffer da Silva ${ }^{2}$ \\ ${ }^{1}$ Instituto Oceanográfico da Universidade de São Paulo \\ (Praça do Oceanográfico, 191, 05508-120 São Paulo, SP, Brasil) \\ ${ }^{2}$ Instituto Federal do Paraná \\ (Rua Antônio Carlos Rodrigues, 453, 83215-750 Paranaguá, Paraná, PR, Brasil) \\ **Corresponding author: brandini@usp.br
}

A B STR ACT

Concrete modules were deployed on the bottom of the 11,18 and 30 meters isobaths along a crossshelf hydrographic gradient off Paraná State, Southern Brazil, with the purpose of studying the colonization of sessile epilithic macroinvertebrates on artificial surfaces. After one year of submersion a total of 63 species of epilithic organisms were identified, dominated by Ostrea puelchana, Chthamalus bisinuatus, Balanus cf spongicola, Astrangia cf rathbuni, Didemnum spp, poryphers and bryozoans. Diversity index and percent cover at reef stations placed at 11, 18 and 30 meters isobaths were respectively 2.28 and $66.7 \%, 2.79$ and $96.6 \%$ and 1.66 and $77.4 \%$. Differences of general community structure among the three assemblages were not clearly related to the general environmental conditions at the bottom layers near the reef stations. Turbidity and larval abundance are discussed as important factors affecting colonization processes. Results indicate that depths between 15-20 meters are more suitable for the implementation of large scale artificial reef systems in the inner shelf off Paraná and, possibly, throughout the inner shelves off southern Brazil with similar hydrographic conditions.

\section{RESUMO}

Blocos quadriláteros de concreto foram assentados no fundo marinho nas isóbatas de 11, 18 e 30 metros ao longo de um transecto na plataforma interna perpendicular a costa do estado do Paraná, Região sudeste do Brasil, com o objetivo de analisar a colonização de macroinvertebrados epilíticos em superfícies artificiais em relação ao gradiente ambiental. Após um ano de submersão foram identificadas 63 espécies de organismos epilíticos dominados por Ostrea puelchana, Chthamalus bisinuatus, Balanus cf spongicola, Astrangia cf rathbuni, Didemnum spp, esponjas e briozoários. Os índices de diversidade e porcentagens de cobertura da macrofauna epilítica nos recifes artificiais assentados sobre as isóbatas de 11,18 e 30 metros foram respectivamente 2.28 and $66.7 \%, 2.79$ and $96.6 \%$ and 1.66 and $77.4 \%$. As diferenças entre a estrutura da comunidade epilítica nas tres isóbatas não foram claramente relacionadas com as condições ambientais no fundo próximo aos recifes artificiais. Turbidez e abundância de larvas do meroplâncton foram considerados fatores importantes no controle da colonização epilítica e nas diferenças entre a estrutura das comunidades observada nos tres recifes experimentais. Os resultados indicam que profundidades entre 15 e 20 metros são mais adequadas para a instalação de sistemas de recifes artificiais em larga escala na plataforma do estado do Paraná e, possivelmente, em toda a região Sudeste do Brasil com características hidrográficas semelhantes.

Descriptors: Artificial reefs, Epilithic fauna, Paraná State, Brazil.

Descritores: Recifes artificiais, Fauna epilítica; Paraná, Brazil.

\section{INTRODUCTION}

The inner continental shelf off Paraná State (Lat. 25-26 $\mathrm{S}$ ), southern Brazil, is poor in hard bottom habitats. Almost $99.9 \%$ of the submerged marine floor of $<50$ meters deep is dominated by sandy or muddy

(*) Paper presented at the $9^{\text {th }}$ CARAH - International Conference on Artificial Reefs and Related Aquatic Habitats on 8-13 November, Curitiba, PR, Brazil. bottom sediments depending on the distance from the coast (VEIGA et al., 2004). Except for a few islands, rocky shores and a few submerged natural reefs, the shelf habitat near the coast offers few possibilities for the survival of epilithic and rocky fish communities, despite the high meroplanktonic larval pool (BRANDINI, 2003; CODINA, 2003). Due to this bottom geomorphology, the inner shelf ecosystem has been much impacted in the last decades by shrimp- 
trawlers by-catching non-commercial but important stocks for small-scale fisheries.

Artificial reef programs have been developed in Paraná's inner shelf zone and might help to solve some of these problems since they can protect natural communities against trawling and support the development of other economically sustainable activities such as eco-tourism, sport fishery and offshore mariculture grounds, which benefit coastal communities.

However, the success of artificial reef programs depends primarily on how fast epilithic fauna communities can grow since they occupy low trophic levels in hard bottom ecosystems. It would, therefore, be better if reef units are colonized as quickly as possible to provide food and habitat complexity for new colonizers (FRAZER \& LINDBERG, 1994; BORTONE et al., 2000). Their abundance and species diversity depend on the hydrographic regime and the larval recruitment capacity of the sites at which it is planned to deploy these new habitats (BORTONE et al., 2000; WITMAN \& DAYTON, 2001). The hydrography off Paraná State coast is highly dynamic with well developed vertical and cross-shelf gradients throughout the seasonal cycle (REZENDE AND BRANDINI, 1996; FERNANDES \& BRANDINI,
2004; BRANDINI et al., 2007). Differences are therefore to be expected in epilithic fauna in new habitats placed in close proximity to each other on sandy bottoms at increasing distances from the coast.

The purpose of this investigation is to evaluate the development of epilithic communities on experimental artificial reefs in relation to cross-shelf environmental gradients in order to select the best sites for large-scale artificial reef programs in Paraná State.

\section{Material and Methods}

Study Area

The Paraná inner shelf $(<50 \mathrm{~m})$ is a minor portion of the South Brazil Bight between $25^{\circ} 12^{\prime} \mathrm{S}$ and $25^{\circ} 58^{\prime} \mathrm{S}$ and $48^{\circ} 35^{\prime} \mathrm{W}$ much affected by the continental runoff from the estuarine bays of Paranaguá and Guaratuba. The near-shore bottom is muddy with 10 to $40 \%$ rates of silt and clay between the 5 and 15 meter isobaths due to large amounts of fine particles flushed out by ebb tidal currents from the bays. A few miles offshore bottom sediments gradually give way to well-sorted and coarse-grained sand (VEIGA et al., 2004).

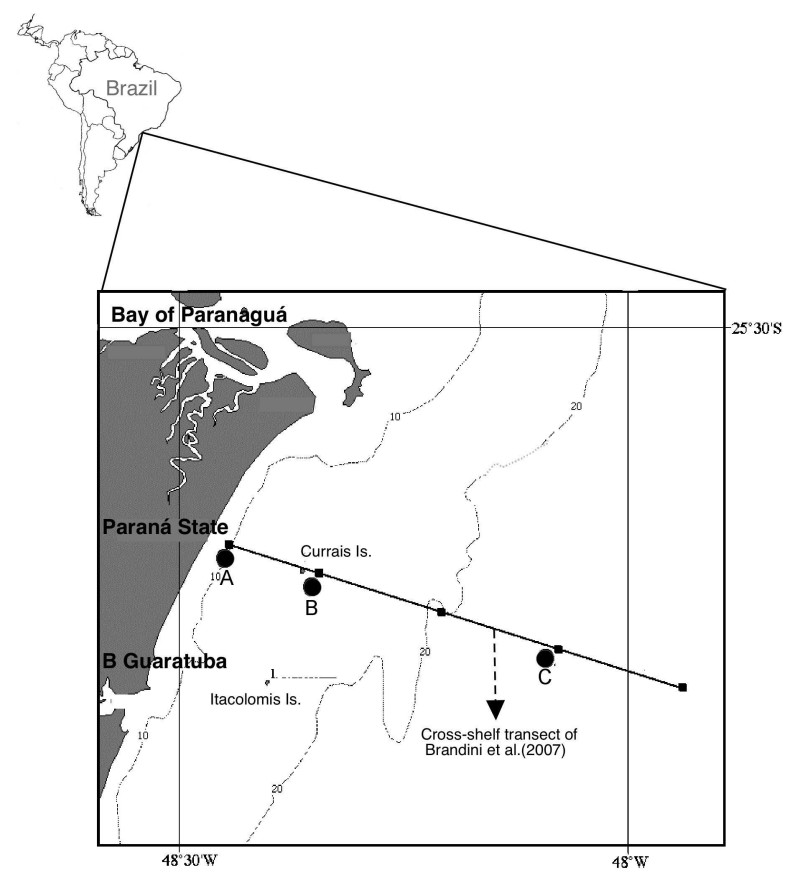

Fig. 1. Map of the hydrographic cross-shelf transect with positions of the experimental sites A, B and C in the inner shelf of Paraná State, southeastern Brazil. 
In summer seasons (December-March), surface waters tend to be driven offshore by persistent winds from the northeast due to Ekman transport allowing coastward bottom intrusions of the colder and nutrient rich waters of the South Atlantic Central Water-SACW (CASTRO FILHO et al., 1987). In winter (June-August), the persistence of southwest winds cause an onshore convergence of physically homogeneous and less saline shelf waters due to the remote freshwater discharges of the La Plata River and the Patos Lagoon estuary (PIOLA et al., 2000).

The seasonal patterns of the hydrographic regime on the inner-shelf $(<50 \mathrm{~m})$ have been studied by Brandini et al. (2007). They reported strong crossshelf temperature gradients, mostly in spring (September-November) and summer (DecemberFebruary), seasons when the thermocline is well developed in waters deeper than 25 meters. In autumn (March-May), thermal stratifications are less evident but residues of vertical gradients may still be detected on the bottom. In winter (July-August) most thermal gradients tend to disappear due to wind and tidally induced vertical circulation.

\section{Deployment of experimental reefs}

On 4th January 1997, concrete blocks of $1 \mathrm{x}$ $0.8 \times 0.8 \mathrm{~m}\left(=0.64 \mathrm{~m}^{3} ; 600 \mathrm{Kg}\right)$, similar to those used by Lindberg (1996), were deployed on the sea floor of the 11 (reef stn A), 18 (reef stn B) and 30 (reef stn C) meter isobaths along the same hydrographic transect as was studied by Brandini et al.(2007). Due to logistic and space limitation on board, the number of blocks at each reef station was different, with 4 blocks at reef station A, 9 blocks at B and 18 blocks at C. The general arrangements of block units at each reef station are depicted in Figure 2.

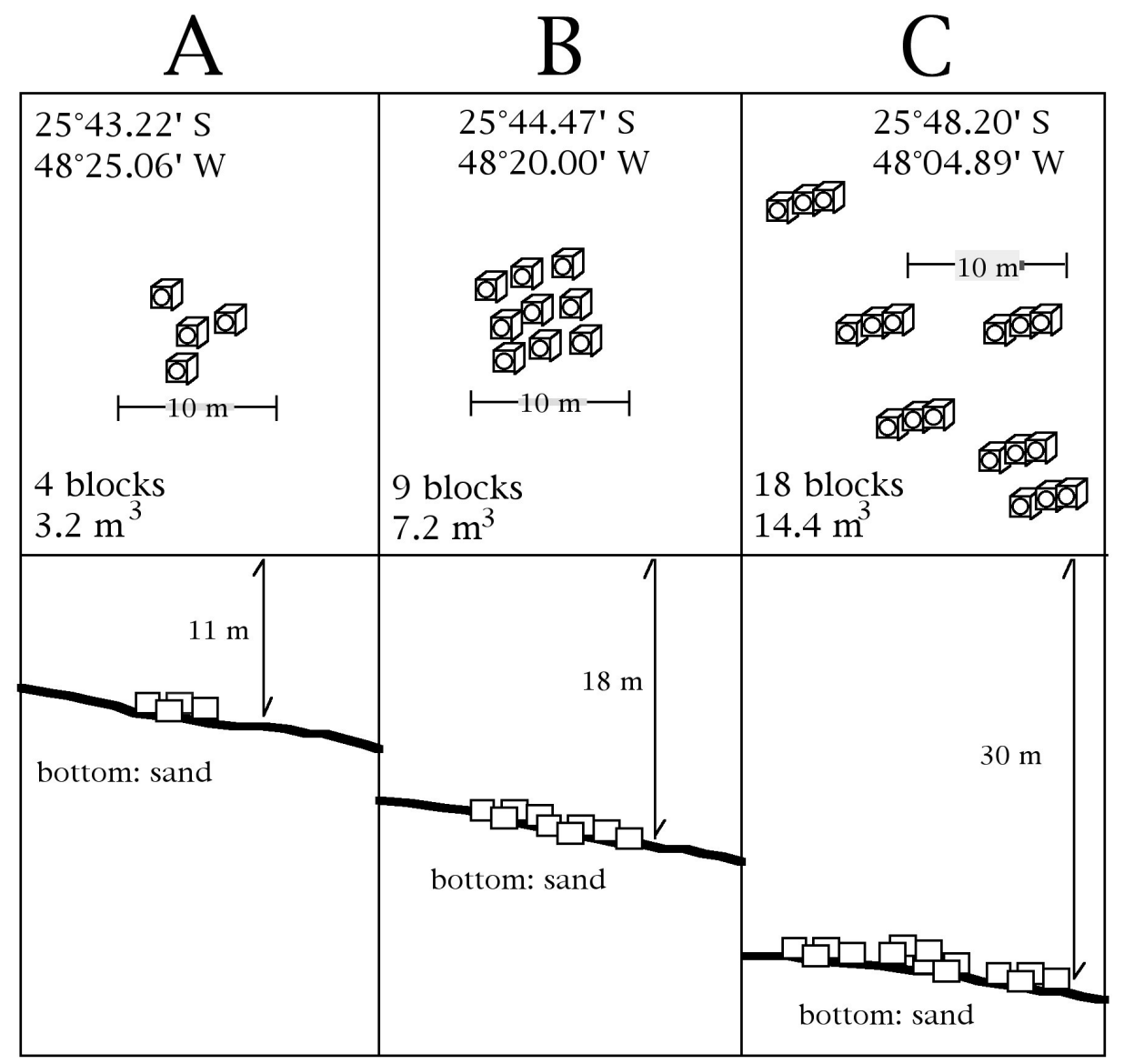

Fig. 2. Reef stations position, general characteristics and final spatial arrangements of concrete block units after deployment in 4th January 1997 at the inner shelf of Paraná State, southeastern Brazil. 
Hydrographic Parameters

The environmental data of the bottom layers near the reef stations were taken from Brandini et al. (2007). Six months after the deployment of the reef sets, the authors started a monthly sampling program which lasted from August 1997 to March 1999 in order to ascertain the hydrographic conditions along the same cross-shelf transect on which the reefs A, B and $\mathrm{C}$ had been deployed. After Secchi disk readings, water samples were taken with a 1.5 liter Hydrobios sampler and temperature-salinity data with a miniCTD (SD 202) at the bottom near each reef station. Turbidity was also measured at the bottom, but only after June 1998, the results being reported here in millivolts, i.e. the output voltage of an OBS3 sensor.

Zooplankton samples were collected at approximately monthly intervals at each reef station during a one-year cycle from August 1997 to August 1998, with a $200 \mu \mathrm{m}$ mesh plankton net. This was hauled vertically from the bottom to the surface to analyze the meroplanktonic larval pool in the water column near the artificial reefs. Net samples were fixed with $4 \%$ buffered formaldehyde solution and later analyzed at the lab under a stereo-microscope. The whole zooplankton sample was analyzed and densities of meroplanktonic larvae presented as number of organisms per volume of sea water (V) filtrated by the net. This was estimated by the equation $\mathrm{V}(\mathrm{m} 3)=\pi \cdot \mathrm{R} 2 . \mathrm{h}$, where $\mathrm{R}$ is the radius of the net mouth $(30 \mathrm{~cm})$ and $\mathrm{h}$ the water column's depth.

\section{Analysis of the Epilithic Fauna}

In January 1998 (i.e., one year after submersion) the composition and percentage cover of epilithic macro-invertebrates which had occupied the reef block surfaces were analyzed. Only sessile groups underwent analysis. Underwater photography was used to quantify colonial and solitary species over a predetermined quadrant of $16.4 \times 10.8 \mathrm{~cm}(=177 \mathrm{~cm} 2)$. Photographic samples were taken with a Nikonus V® camera equipped with $35 \mathrm{~mm}$ lens to which a macro lens had been adapted. Light was provided by a YS$50 \AA$ submarine flash. A total of 12 photographic 35 $\mathrm{mm}$ slides (Ektachrome 100) were taken of the vertical sides of the concrete modules at each experimental site. These were overlaid with an acetate template with 50 perforations regularly distributed over its surface (BOHNSACK, 1979). Organisms inside the perforations were identified under the stereo microscope. The number of species and the ShanonWeaver Index were used to estimate mean (out of 12) percent cover and diversity at the experimental points. Unidentified species were listed according to the general form and color patterns. A destructive method was also used to help taxonomic identification in a few cases. Attached organisms were scraped off from the walls of the concrete modules and preserved in a $4 \%$ formaldehyde + filtrated seawater solution for later identification.

The Analysis of Variance (ANOVA - p $<0.05)$ was used to compare the mean values of percentage cover as between experimental sites. The Bray-Curtis Index was used $(p<0.05)$ to assess the similarity among mean abundances of sessile organisms. Dendrograms of the communities at the three experimental sites were analyzed by Hierarchical Clustering. Non-metric Multidimensional scaling was used to represent dissimilarity among assemblages.

\section{RESULTS}

\section{Environmental Conditions at Reef Stations}

Despite the period's dedicated to the measurements being short, turbidity was very obviously much higher at the nearshore stations A and $B$ than at the outer and deeper reef station C, especially in October-November 1999 (Fig.3a). Secchi disk readings varied from $1.5 \mathrm{~m}$ at coastal reef station A in September 1997 to $14 \mathrm{~m}$ at the outer most reef station C in August 1998 (Fig. 3b). Seasonal patterns at stations $\mathrm{A}$ and $\mathrm{B}$ decreased similarly during the summer rainy periods between September-March of 1998 and 1999 and increased in winter between May and August 1998. Seasonal patterns of temperature and salinity were almost the same at both the nearshore reef stations $\mathrm{A}$ and $\mathrm{B}$, with temperatures ranging from $26-28^{\circ} \mathrm{C}$, and salinities between 34 and 36 in the first half of the study period, dropping to 3331 from June to November 1998 (Figs 3c, d). Except for light, environmental conditions at the outermost reef station $\mathrm{C}$ were quite different. There salinity was always higher, mainly in the second half of the study period, varying between 36 and 37 except in July 1998 when it dropped to $<34$. The seasonal variation of bottom temperature was also different at the outer station C. Except for the late spring and winter periods (e.g., August-September 1997 and April-August 1998), temperatures were usually lower especially during the autumn-summer periods of November 1997-January 1998 and October-December 1998. Dissolved oxygen concentration varied irregularly from 3.3 to 5.3 mg.L-1 without any clear seasonal patterns at any of the reef sites (Fig. 3e).

Figure 4 shows just the dominant larval groups in the plankton. Density of meroplanktonic larvae at the reef stations varied irregularly throughout the annual cycle. Density of polychaetes's trochophore ranged usually below 100 org.m-3 with peak densities up to 500 at station B and $200 \mathrm{org} \cdot \mathrm{m}^{3}$ at reef station A in Februry 1998. Minor peaks occurred in April and August 1998 at station B and exceptionally at the 
outermost station C in late April 1998. bivalves's veliger were the second in dominance of the invertebrate larval pool. They were more abundant at the near-shore stations A and B in the first half of the annual cycle with densities ranging around 200 org. $\mathrm{m}^{3}$. In the second half of the sampling period densities were higher at the outer station $\mathrm{C}$ usually around $100 \mathrm{org} \cdot \mathrm{m}^{3}$ with a peak of $160 \mathrm{org} \cdot \mathrm{m}^{3}$ in July. Very low densities of barnacles, cnidarian and criozoan larvae, usually one order of magnitude less than those of polychaete and bivalves, were found at the nearshore reef stations A and B. Densities of barnacle's larvae were usually $<10$ org. $\mathrm{m}^{3}$ with only two peaks of 18 org. $\mathrm{m}^{3}$ in April at station A and 49 org. $\mathrm{m}^{3}$ in August 1998 at station B. Although rare at all the reef stations, larvae of barnacles, briozoans and cnidarians were more abundant at reef station B where peak concentrations of the dominant larvae of polychaete and bivalves also occurred. At the outer reef station $\mathrm{C}$ the larval pool was very small, usually dominated by veligers. Larvae of other taxonomic groups were rarely observed in the plankton samples especially at the outer reef station C, except for the larger pool of veligers between April and July 1998. During most of the study period larval densities were null or rarely exceeded 1 org. $\mathrm{m}^{3}$ except for the peak of cnidarian larvae $\left(15\right.$ org. $\left.\mathrm{m}^{3}\right)$ in January 1998.

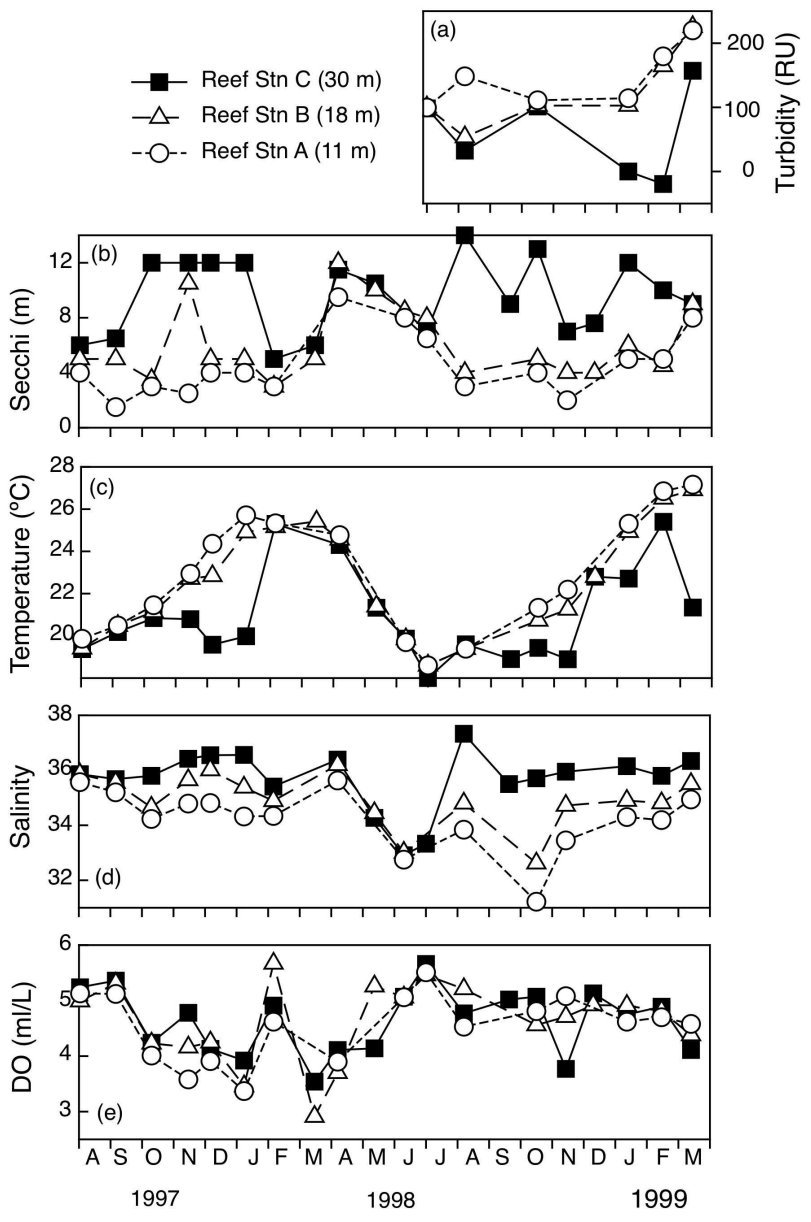

Fig. 3. Seasonal variation of environmental parameters at the bottom layers near reef stations A, B and C in the inner shelf of Paraná State, southeastern Brazil. 

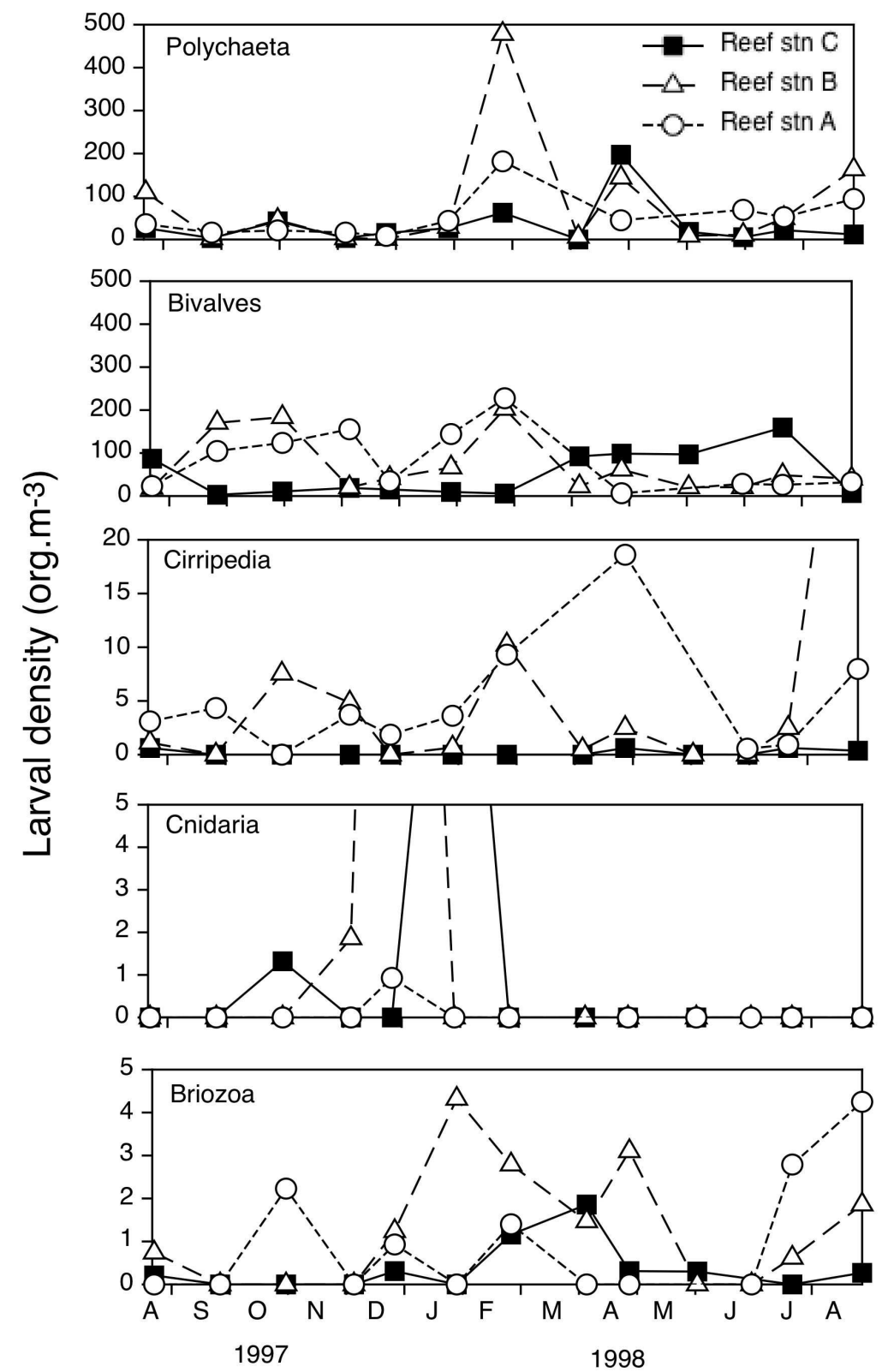

Fig. 4. Seasonal variation of the abundance of dominant invertebrate larvae in the water column near reef stations $\mathrm{A}, \mathrm{B}$ and $\mathrm{C}$ in the inner shelf of Paraná State, southeastern Brazil.

\section{Epilithic Fauna}

A total of 63 species of epilithic macroinvertebrates were identified, 38 at reef station $\mathrm{A}\left(\mathrm{H}^{\prime}=\right.$ $2.28), 56$ at $\mathrm{B}\left(\mathrm{H}^{\prime}=2.79\right)$ and 30 at $\mathrm{C}\left(\mathrm{H}^{\prime}=1.66\right)$ (Table 1). There were 9 species of ascidians, 19 cnidarians ( 8 anthozoans +11 hydroids), 10 sponges, 9 molluscs ( 8 bivalves +1 gastropod), 3 barnacles and
6 polychaetes. Some individuals occurred exclusively at one site. For example, Zoanthus sp at reef A. Symplegma sp, Haliclona sp, Clytia gracilis, Dentitheca sp, Carditamera moridaria, Polydora sp and the hydroids sp 1 , sp 2 and sp 3 were all found only at reef B; Ellisela elongata, Lophogorgia puniceae, Cliona $\mathrm{sp}$, hydroid $\mathrm{sp} 4$ and Balanus cf spongicola were found only at reef C. Dominant 
species were considered those with a relative contribution of total percentage cover of more than 5 $\%$ at least at one of the sites. Different distributional patterns were observed among dominant species (Table 2). For instance, Chthamalus bisinuatus and serpulid polychaetes decreased from reef A to C. Astrangia rathbuni, Didemnum spp, Ostrea puelchana, Halocordyle disticha and sponges were more successful at reef $\mathrm{B}$, although the hydrozoan was successful at point $\mathrm{A}$ as well. Bryozoa sp 3 develop similarly at B and $\mathrm{C}$ but not at A. Balanus cf spongicola dominated, but exclusively at $\mathrm{C}$. The relative contributions of other species were below 5\% but together they have colonized more than $50 \%$ of the concrete surfaces of reef B where species richness and total percentage cover were highest. The mean (i.e., out of 12 slides) percentage cover at points A, B and C were, respectively, 66.7, 96.6 and $77.4 \%$ (Fig. 5). The ANOVA showed significant differences among the mean abundances for $50 \%$ of the species found at the three reef stations. Blocks of the reef station B (18 meters) were almost totally colonized compared to the high percentage of void space in the blocks of reef stations A $(11 \mathrm{~m})$ and $\mathrm{C}(30 \mathrm{~m})$. The three macroepilithic assemblages were clearly separated at the $40 \%$ level by the statistical analysis, except for the two photographic samples 9RA and 1RC taken at reef stations $\mathrm{A}$ and $\mathrm{C}$, respectively, which were dissimilar at the $38 \%$ level in relation to the main groups (Fig. 6).

Table 1. List of especies and percent cover of epilithic macro invertebrates at three experimental sites off Parana inner shelf.

\begin{tabular}{|c|c|c|c|}
\hline \multirow[t]{2}{*}{ group/species } & \multicolumn{3}{|c|}{ Experimental site $^{1}$} \\
\hline & $\mathbf{A}$ & $\mathbf{B}$ & $\mathbf{C}$ \\
\hline \multicolumn{4}{|l|}{ Tunicates } \\
\hline Didemnum 1 & 1.8 & 3.3 & 1.5 \\
\hline Didemnum 2 & 1.1 & 2.5 & 0.6 \\
\hline Diplosoma listerianum & 0.9 & 0.4 & 0.8 \\
\hline Botrillus tuberatus & 0.3 & 0.6 & 0.0 \\
\hline Symplegma sp & 0.8 & 0.0 & 0.0 \\
\hline Ascidian sp colonial & 0.0 & 0.4 & 0.2 \\
\hline Ascidian sp 1 & 0.8 & 0.8 & 0.0 \\
\hline Ascidian sp 2 & 0.5 & 0.6 & 0.0 \\
\hline Ascidian sp 3 & 0.0 & 0.8 & 0.8 \\
\hline \multicolumn{4}{|l|}{ Anthozoans } \\
\hline Astrangia of rathbuni & 0.3 & 8.7 & 3.1 \\
\hline Phyllangia cf americana & 0.8 & 0.8 & 0.0 \\
\hline Madracis cf decactis & 0.0 & 1.0 & 0.2 \\
\hline Palythoa caribeorum & 0.9 & 0.4 & 0.0 \\
\hline Zoanthus sp & 0.3 & 0.0 & 0.0 \\
\hline Carijoa riisei & 1.5 & 0.4 & 0.0 \\
\hline Elisela elongata & 0.0 & 0.0 & 0.5 \\
\hline Lophogorgia punicea & 0.0 & 0.0 & 0.3 \\
\hline \multicolumn{4}{|l|}{ Bryozoans } \\
\hline encrusting sp 1 & 0.8 & 0.0 & 0.6 \\
\hline encrusting sp 2 & 0.3 & 1.0 & 0.0 \\
\hline Schyzoporela sp & 0.2 & 1.2 & 0.6 \\
\hline Bugula sp & 1.2 & 2.5 & 0.0 \\
\hline Bryozoa sp 1 & 1.3 & 0.5 & 0.0 \\
\hline Bryozoa sp 2 & 0.3 & 0.4 & 0.0 \\
\hline Bryozoa sp 3 & 0.0 & 3.4 & 3.5 \\
\hline \multicolumn{4}{|l|}{ Hydrozoans } \\
\hline Halocordyle disticha & 2.6 & 3.2 & 0.8 \\
\hline Bougainvillia rugosa & 1.0 & 1.3 & 0.0 \\
\hline Clytia gracilis & 0.0 & 1.1 & 0.0 \\
\hline Dentitheca sp & 0.0 & 1.5 & 0.0 \\
\hline Dynamena sp & 1.2 & 1.3 & 0.0 \\
\hline Obelia sp & 2.3 & 2.7 & 0.0 \\
\hline Sertularia $s p$ & 0.8 & 1.7 & 0.0 \\
\hline Hidroid sp 1 & 0.0 & 1.4 & 0.0 \\
\hline Hidroid sp 2 & 0.0 & 0.4 & 0.0 \\
\hline Hidroid sp 3 & 0.0 & 0.4 & 0.0 \\
\hline Hidroid sp 4 & 0.0 & 0.0 & 2.8 \\
\hline \multicolumn{4}{|l|}{ Sponges } \\
\hline Mycale $\mathrm{sp}$ & 0.0 & 1.0 & 0.3 \\
\hline Mycale microstigmato & 0.2 & 1.3 & 0.3 \\
\hline M. magnirhaphidifera & 0.0 & 0.8 & 0.8 \\
\hline Haliclona $\mathrm{sp}$ & 0.0 & 1.0 & 0.0 \\
\hline Cliona sp & 0.0 & 0.0 & 1.2 \\
\hline
\end{tabular}


Table 1. Continuation.

\begin{tabular}{|c|c|c|c|}
\hline \multirow[t]{2}{*}{ group/species } & \multicolumn{2}{|c|}{ Experimental site $^{1}$} & \multirow[b]{2}{*}{ C } \\
\hline & $\mathbf{A}$ & B & \\
\hline Tedania sp (orange) & 0.0 & 0.0 & 5.4 \\
\hline sponge sp 1 reticulada & 0.8 & 0.7 & 0.0 \\
\hline sponge sp 2 (grey) & 0.2 & 18.1 & 5.8 \\
\hline sponge sp 3 (browm) & 0.0 & 0.6 & 1.3 \\
\hline sponge sp 4 (yellow) & 0.0 & 7.4 & 4.3 \\
\hline \multicolumn{4}{|l|}{ Molluscs - Bivalves } \\
\hline Ostrea $s p$ & 4.0 & 6.5 & 1.9 \\
\hline Spondilus americanus & 0.1 & 0.9 & 0.0 \\
\hline Arca imbricata & 0.4 & 1.3 & 0.0 \\
\hline Modiolus carvalhoi & 0.3 & 0.8 & 0.2 \\
\hline Carditamera moridaria & 0.0 & 0.4 & 0.0 \\
\hline Chama sp & 0.3 & 0.8 & 0.0 \\
\hline Pteria sp & 0.0 & 1.2 & 0.1 \\
\hline Nodipecten nodosus & 0.2 & 0.8 & 0.0 \\
\hline \multicolumn{4}{|l|}{ Mollucs - Gastropods } \\
\hline Crepidula $s p$ & 0.8 & 0.7 & 0.0 \\
\hline \multicolumn{4}{|l|}{ Mollucs - Gastropods } \\
\hline Crepidula $s p$ & 0.8 & 0.7 & 0.0 \\
\hline \multicolumn{4}{|l|}{ Barnacles } \\
\hline Megabalanus $s p$ & 0.0 & 0.7 & 0.4 \\
\hline Balanus cf spongicola & 0.0 & 0.0 & 37.2 \\
\hline Chthamalus bisinuatus & 7.1 & 1.3 & 0.0 \\
\hline \multicolumn{4}{|l|}{ Polychaetes } \\
\hline Chaetopteridae spl & 10.6 & 0.3 & 0.0 \\
\hline Polychaeta sp 1 & 2.9 & 0.4 & 0.0 \\
\hline Polychaeta sp 2 & 0.0 & 0.6 & 0.6 \\
\hline Polychaeta sp 3 & 0.3 & 0.6 & 0.0 \\
\hline Polydora sp & 0.0 & 0.2 & 0.0 \\
\hline Serpulidae & 7.3 & 2.5 & 0.6 \\
\hline
\end{tabular}

${ }^{1} \mathrm{~A}-11 \mathrm{~m} ; \mathrm{B}-18 \mathrm{~m} ; \mathrm{C}-30 \mathrm{~m}$

Table 2. Mean percent cover of dominant epilithic macro invertebrates on artificial reefs deployed over the inner shelf off Paraná State, Southeastern Brazil.

\begin{tabular}{|c|c|c|c|}
\hline Organism & Reef $\operatorname{Stn}^{1}$ & Mean $\mathrm{PC}^{2}$ & SD \\
\hline \multirow[t]{3}{*}{ Chthamalus bisinuatus } & A & 7.08 & 6.70 \\
\hline & $\mathrm{B}$ & 1.33 & 1.23 \\
\hline & $\mathrm{C}$ & - & - \\
\hline \multirow[t]{3}{*}{ Serpulidae } & $\mathrm{A}$ & 7.25 & 6.26 \\
\hline & $\mathrm{B}$ & 2.50 & 3.34 \\
\hline & $\mathrm{C}$ & 0.50 & 0.79 \\
\hline \multirow[t]{3}{*}{ Astrangia rathbuni } & A & 0.25 & 0.62 \\
\hline & B & 8.66 & 7.21 \\
\hline & C & 3.08 & 5.17 \\
\hline \multirow[t]{3}{*}{ Ostrea pulchana } & A & 4.00 & 2.62 \\
\hline & $\mathrm{B}$ & 6.50 & 3.08 \\
\hline & $\mathrm{C}$ & 1.91 & 3.08 \\
\hline \multirow[t]{3}{*}{ Halocordyle disticha } & A & 2.58 & 5.52 \\
\hline & $\mathrm{B}$ & 3.16 & 2.16 \\
\hline & $\mathrm{C}$ & 0.83 & 1.19 \\
\hline \multirow{3}{*}{ Sponge sp 2 (grey) } & $\mathrm{A}$ & 10.1 & 8.48 \\
\hline & $\mathrm{B}$ & 18.0 & 12.4 \\
\hline & $\mathrm{C}$ & 5.75 & 8.40 \\
\hline \multirow[t]{3}{*}{ Sponge sp 4 (yellow) } & $\mathrm{A}$ & - & - \\
\hline & B & 7.41 & 6.86 \\
\hline & $\mathrm{C}$ & 4.33 & 8.47 \\
\hline \multirow[t]{3}{*}{ Didemnum spp } & A & 2.83 & 2.75 \\
\hline & B & 5.75 & 5.34 \\
\hline & $\mathrm{C}$ & 2.08 & 1.50 \\
\hline \multirow{3}{*}{ Bryozoan sp 3 (branched) } & A & - & - \\
\hline & B & 3.41 & 4.66 \\
\hline & C & 3.50 & 3.60 \\
\hline \multirow[t]{3}{*}{ Balanus spongicula } & A & - & - \\
\hline & B & - & - \\
\hline & $\mathrm{C}$ & 37.1 & 19.3 \\
\hline
\end{tabular}

${ }^{1} \mathrm{~A}-11 \mathrm{~m} ; \mathrm{B}-18 \mathrm{~m} ; \mathrm{C}-30 \mathrm{~m}$

${ }^{2} \mathrm{~N}=12$ 


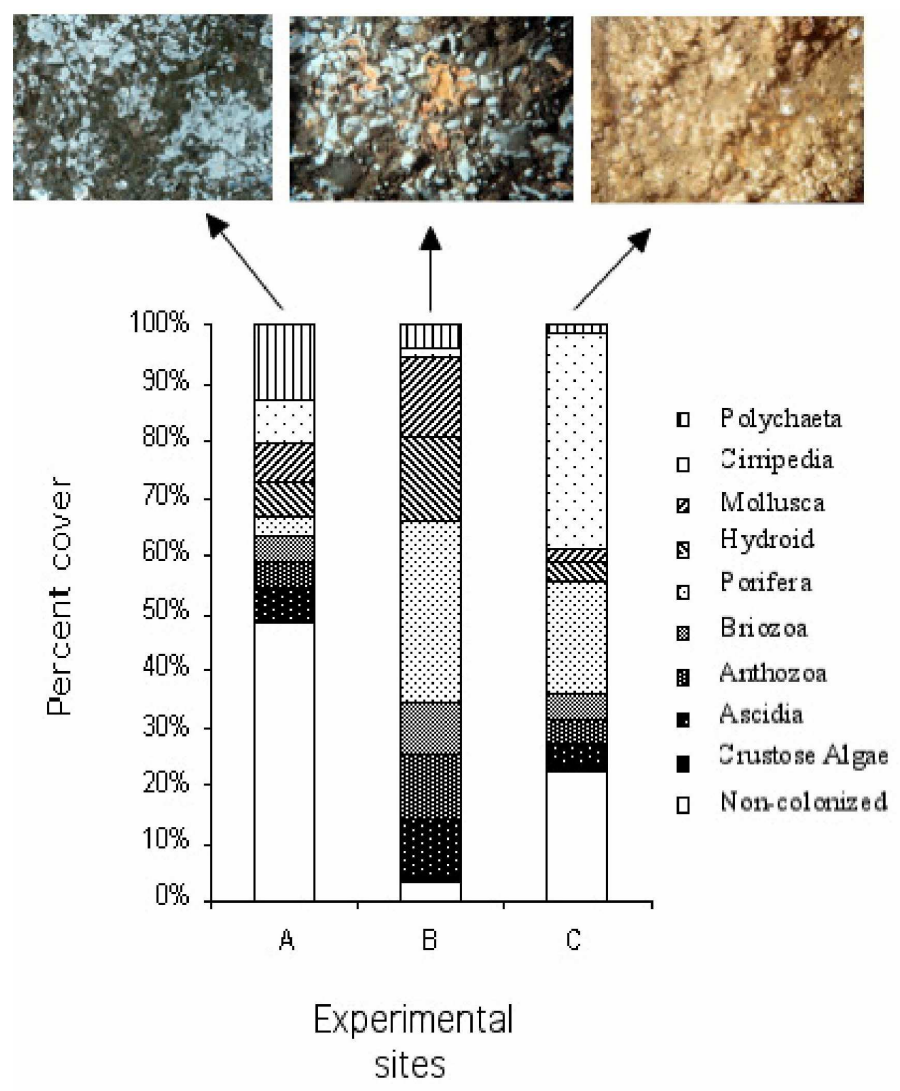

Fig.5. Percent cover and void space for dominant epilithic invertebrates developed on artificial reefs submerged during one year in the inner shelf of Paraná State, southeastern Brazil.

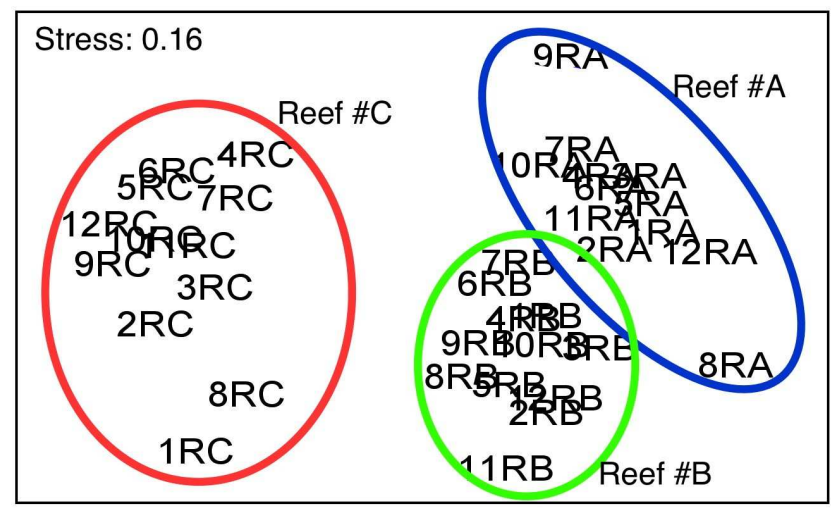

Fig. 6. n-MDS plots of dissimilarity among epilithic assemblages developed during one year at reef stations $\mathrm{A}, \mathrm{B}$ and $\mathrm{C}$ in the inner shelf of Paraná State, southeastern Brazil. 


\section{Discussion}

The sessile assemblages found at the three reef stations were not as rich and diversified as those of the nearby rocky habitats on Currais Island (Silva, 2001). The new reefs were not large enough and maybe had not been submerged for long enough to replicate the natural community of the nearby natural rocky habitats. In addition, none of the reef stations has bottom light intensity sufficient to support algal growth to feed herbivores, which limits resources for the new colonizers. These were mostly suspension and filter feeders which had to rely on sedimentation and/or advection of organic particles. Using the Secchi data of Brandini et al. (2007) and the Beer-Lambert equation that describes the exponential light attenuation in the water column, we found the mean euphotic zone and \% surface light at each reef station $\mathrm{A}, \mathrm{B}$ and $\mathrm{C}$ to be, respectively, 10.6, 16.4 and 25.5 meters and 0.6, 0.5 and $0.24 \%$. All the reef communities have thus been developed under very light-limited conditions, usually below the compensation point for autotrophic growth. In spite of the few data measurements taken, turbidity at the bottom layers near the reefs was in fact always higher at the near-shore reefs A and B than at C (see Fig.3a). However, depth decreased gradually from $\mathrm{A}$ to $\mathrm{C}$ and, therefore, the light conditions were similar at all the reef stations and may not account for the differences in their macro-invertebrate fauna.

Except for the few months of physical stratification (BRANDINI et al., 2007) when differences of bottom temperatures at all the reef stations were enhanced, temperatures were usually very similar at all the reef stations during at least half of the study period. The lower temperatures at the bottom at reef $\mathrm{C}$ are due to onshore intrusions of cold SACW, balancing the offshore Ekman transport of coastal and less saline waters by northeast winds which prevail during the summer seasons in the study area (CASTRO-FILHO et al., 1987; BRANDINI et al., 2007). However, these were not strong enough to reach the outer and deeper water column over reef station $\mathrm{C}$, keeping salinities always higher than at the two near-shore reef stations, except in the winter of 1998, between June and August, when salinities dropped at the bottom at the outer reef station $\mathrm{C}$ to the same levels as at the nearshore reef stations A and B. This might be associated with the winter advection of inner shelf waters with lower salinities due to the discharges of the La Plata River and Patos Lagoon estuary, brought to the study area by southwesterly winds (PIOLA et al., 2000). Finally, oxygen concentrations are not limiting respiratory processes at any of the three reef stations and may not account for the differences in their epilithic assemblage.
Overall, the standard hydrographic parameters measured at the three reef stations did not explain the large differences in epilithic fauna composition and abundance between the nearshore reef stations $\mathrm{A}$ and $\mathrm{B}$ and that at $\mathrm{C}$. Abundance and richness of epilithic macroinvertebrates were twice as high at reef $\mathrm{B}$ than at the shallower reef $\mathrm{A}$ and deeper reef $\mathrm{C}$, and diversity was much higher at the nearshore reefs $\mathrm{A}$ and $\mathrm{B}$ as compared to C. On the other hand, suspended particles and potential larval recruitment may play an important role in the colonization processes of the study area. Obviously, both proximity to continental drainage at the near-shore stations and sediment re-suspension due to tidal currents and windinduced turbulence increase water turbidity (QUEIROZ et al., 2004; BRANDINI et al., 2007). This certainly limits colonization more at reef station A (i.e., at 11 meter depth) because meroplanktonic larvae, although as abundant as at reef B, were outcompeted by the constant loads of particulate material settling on the new substrates. This is supported by the usually higher turbidity measured in the study area, together with visual inspections and photographic images taken of the top surfaces of the concrete blocks. The outer and deepest reef $\mathrm{C}$ was much less affected by suspended particles. However, the lower rate of colonization, with more void space than that at the nearshore reefs, suggests a certain degree of limitation of recruitment. In fact, the mean meroplanktonic larval pool observed in this investigation tends to decrease with distance from the coast, as previously reported for the study area (BRANDINI, 2003; CODINA, 2003). The intermediate reef $\mathrm{B}$ on the 18 meter isobath was less subject to bottom turbidity than was reef station A, the closest to the coast, and had slightly higher water transparency. In addition, due to the proximity of rocky shores, the potential for larval recruitment at this intermediate depth is clearly much better than at the outermost reef $\mathrm{C}$, which is in fact the most recruitment-limited area of the inner shelf.

We conclude, therefore, that waters with 1520 meter depths, where bottom and hydrographic conditions are similar to those observed at reef station $\mathrm{B}$, are more suitable for the rapid colonization of artificial reefs with epilithic communities and hence better for the development of artificial reef projects off the coast of Paraná state. This intermediate sector of the inner shelf, although at the edge of the turbidity front, still has a sufficient larval pool to guarantee rapid epilithic colonization.

\section{ACKNOWLEDGEMENTS}

We thank the Brazilian Navy and all the crew members of the support vessel "Mario Seixas" for the installation of the 31 concrete blocks used for 
the experiment. This paper was financially supported by the Brazilian Ministry of Science and Technology (PADCT III/CIAMB/Proc. 620408/98-7).

\section{REFERENCES}

BOHNSACK, J. A. Photographic quantitative sampling of hard-bottom benthic communities. Bull. mar. Sci., v.29, n.2, p.242-252, 1979

BORTONE, S. A.; SAMOILYS, M. A.; FRANCOUR, P. Fish and macroinvertebrate evaluation methods. In: SEAMAN, JR., W. (Ed.). Artificial reef evaluation with application to natural marine habitats. Boca Raton, Fla.: CRC Press, 2000. p.127-164. (Marine Sciences Series).

BRANDINI, F. P. Recifes Artificiais Marinhos - Uma proposta de conservação da biodiversidade e desenvolvimento da pesca artesanal através da criação de um "Parque Marinho" na costa do Estado do Paraná. Brasília, DF: Ministério da Ciência e Tecnologia, PADCTIII/CIAMB/Proc. 620408/98-7, 2003. (Unpublished Report).

BRANDINI, F. P.; SILVA, A. S.; SILVA, E. T.; KOLM, H. E. Sources of nutrients and seasonal dynamics of chlorophyll in the inner shelf off Paraná State - South Brazil Bight. J. coast. Res., v.23, p.200-226, 2007.

CASTRO FILHO, B. M.; MIRANDA, L. B.; MIYAO, S. Y. Condições hidrográficas na plataforma continental ao largo de Ubatuba: variações sazonais e em média escala Bolm Inst. Oceanogr., São Paulo, v.35, p.135-151, 1987.

CODINA, J. C. U. Dinâmica sazonal das larvas de moluscos na plataforma continental interna do Estado do Paraná. 2003. 61 p. Dissertação (Mestrado), Universidade Federal do Paraná, 2003.

FERNANDES, L. F.; BRANDINI, F. P. Diatom associations in shelf waters off Parana State, Southern Brazil: annual variations in relation to environmental factors. Rev. Bras. Oceanogr., São Paulo, v.52, n. 1, p.19-34, 2004.

FRAZER, T. K.; LINDBERG., W. J. Refuge spacing similarly affects reef-associated species from three phyla. Bull. mar. Sci., v.55, n.2-3, p.388-400, 1994.
LINDBERG, W. J. Fundamental design parameters for artificial reefs: Interaction of patch reef spacing and size. The Office of Fisheries management and Assistance Services, Division of Marine Resources, Florida Department of Environmental Protection. Grant C-6729. Final Project Report, 1996.

QUEIROZ, R. L. V.; BRANDINI, F. P.; PELLIZARI, F. M. Dynamics of microalgal communities in the watercolumn/sediment interface of the inner shelf off Parana State, southern Brazil. Rev.Bras. Oceanogr., São Paulo, v. 52, n. 3/4, p.183-194, 2004.

PIOLA, A. R.; CAMPOS, E. J. D.; MÖLLER, JR., O. O.; CHARO, M.; C. MARTINEZ. The subtropical shelf front off eastern South America. J. geophys. Res., v.105, p.6565-6578, 2000.

REZENDE, K. R. V.; BRANDINI, F. P. Variação sazonal do fitoplâncton na zona de arrebentação na Praia de Pontal do Sul (Pontal do Paraná, PR). Neritica,v.10, p.12-23, 1997.

VEIGA F.A; ANGULO R. J.; MARONE E.; BRANDINI, F.P. Shoreface sedimentology at Paraná middle coast. Bolm parana. Geoci., v. 55, p.67-75, 2004.

WITMAN, J.D.; DAYTON, P. K. Rocky subtidal communities. .In: BERTNESS, M.D.; GAINES, S.D.; HAY, M.E. (Ed.). Marine Community Ecology. Sunderland, Mass.: Sinauer Associates, p.339-366, 2001.

(Manuscript received 28 April 2010; revised 27 March 2011; accepted 11 April 2011) 